\title{
The Association Between Spiritual Wellbeing and Dietary Intake Among Overweight and Obese Female University Student: A Cross-Sectional Study
}

Siti Zuhaidah Shahadan ${ }^{1}$, Nursyahidah Atirah Md Ali ${ }^{2}$, Mohamad Firdaus Mohamad Ismail ${ }^{3^{*}}$ ${ }^{1}$ Department of Medical Surgical Nursing, Kulliyyah of Nursing, International Islamic University Malaysia, Pahang, Malaysia.

2Emergency Department, IIUM Medical Specialist Centre, Pahang, Malaysia.

${ }^{3}$ Department of Professional Nursing Studies, Kulliyyah of Nursing, International Islamic University Malaysia, Pahang, Malaysia.

\begin{abstract}
Introduction: Obesity has become a public health threat worldwide and processing a high burden to the healthcare system. This study aimed to determine the association between spiritual wellbeing and dietary intake among overweight and obese female students in a university in Peninsular Malaysia.

Methods: This is a cross-sectional study involving 100 female students from a public university in the East Coast Region of Peninsular Malaysia. The participants are selected based on inclusion and exclusion criteria. Spiritual wellbeing is measured using an adapted and validated spirituality questionnaire, while the dietary intake was calculated using a 24-hour dietary intake questionnaire. Data were analysed using SPSS version 23 and Nutritionist Pro. Pearson correlation is applied to measure the association between spiritual wellbeing and dietary intake.

Results: Spiritual wellbeing was negatively correlated with dietary intake $(r=-0.026, p=0.797)$. The results showed no significant association between spiritual wellbeing and dietary intake $(\mathrm{p}>0.05)$.

Conclusion: To conclude, there is no significant association between spiritual wellbeing and dietary intake among overweight and obese female students. Future research could add other variables such as the micronutrients and macronutrients into the study can help to get a more significant result. Besides, a large-scale study is also warranted to observe the association between spiritual wellbeing and dietary intake among overweight and obese female university students in Malaysia.
\end{abstract}

Keywords: Overweight, Obesity, Spirituality, Students

\section{*Corresponding author}

Dr. Mohamad Firdaus Mohamad Ismail Department of Professional Nursing Studies, Kulliyyah of Nursing, International Islamic University Malaysia, Jalan Sultan Ahmad Shah, 25200 Kuantan, Pahang, Malaysia.

E-mail: firdausismail@iium.edu.my
Article History:

Submitted: 10 August 2021

Accepted: 13 December 2021

Published: 31 January 2022

ISSN: $2600-898 X$ 


\section{INTRODUCTION}

Obesity and overweight are serious public health problems in developed and developing countries worldwide, including Malaysia. Obesity can impose a significant health burden on individuals by increasing their likelihood of developing non-communicable diseases such as hypertension, diabetes, coronary heart disease, osteoarthritis, depression, and cancer (1). World Health Organization (WHO) stated that in 2016, over 1.9 billion (39\%) adults aged 18 years and above were overweight, and among them, more than 650 million (13\%) adults were obese (2). In 2014, Lee and Wan Muda revealed that the prevalence of obesity among Malaysian adults (17.7\%) was higher than the global prevalence (13\%) (3). Additionally, the prevalence of obesity has been increasing in Malaysia for the previous three decades, and the statistics indicated that females were more likely to be overweight or obese than males (4).

Spiritual wellbeing is an essential domain in this study. Spirituality encompasses a wide range of concepts and meanings. Spirituality is defined as the characteristic or state of being interested in religion or religious concerns. It can also be defined as an organised set of behaviours representing a particular value, belief, or faith (5). Malaysia is a country where most people are Muslim, and the professed religion is Islam. Most Muslims are Malay, making up $61 \%$ of the population in Malaysia (6). Islam is the pillar of spiritual and behavioural guide among Muslims. The Quran and the Sunnah outline how to protect health and live life in a state of purity (7). Additionally, the model by Hassan proposed that Islamic faith can influence religious acts, and religious acts can affect an individual's dietary intake (8). In a nutshell, spirituality is believed to be related to an individual's dietary habits.

According to Michopoulou and Jaunikis, food is associated with spiritual wellbeing, but it is difficult to determine the extent to which spirituality influences an individual's food choices and the extent to which food choices are associated with a group's identity as a result of spirituality (9). There is also little evidence to suggest the existence of a link between spiritual wellbeing and dietary intake, particularly among students in higher educational institutions. Therefore, the goal of this study is to investigate the relationship between spiritual wellbeing and dietary intake among overweight and obese female students enrolled in an undergraduate programme at a university in Peninsular Malaysia.

\section{METHODS}

This study is a cross-sectional study investigating the relationship between spiritual wellbeing and dietary intake among overweight and obese female students in a university in Peninsular Malaysia.

The data were collected between February and September of 2020. After receiving informed consent for this study, participants are given access to an online questionnaire survey. Participants must be Muslim female undergraduate students with a BMI of 23 kilogrammes per metre squared $(\mathrm{kg} / \mathrm{m} 2)$ or higher, be able to read and understand English, and have provided written informed consent. On the other hand, students on study leave and who live outside the campus are excluded from this study. A convenience sampling method was practised for selecting the participants in this study. A total number of 338 students is estimated to be recruited in this study as calculated using a 5\% margin error calculator from the Raosoft sample size. Throughout the data collection period, 250 participants have been invited to participate, and 125 completed the questionnaire. After the evaluation of missing data using the listwise deletion approach, a total number of 100 participants is analysed.

This study utilised a set of questionnaires, which comprise three parts; socio-demographic background, spirituality questionnaire and the 24-hours dietary recall for data collection. The socio-demographic background includes age, past educational background, past medical history, self-reported height, weight and body mass index. The body mass index (BMI) cut off for Asians was adopted in this study, given the lower cut off for overweight and obese categories than the World Health Organization (WHO) classification. Accordingly, participants with a BMI of equal to or more than $\geq 23 \mathrm{~kg} / \mathrm{m}^{2}$ are labelled as overweight, and those with a BMI $\geq$ of $25 \mathrm{~kg} / \mathrm{m}^{2}$ is obese (10). 
Additionally, the questionnaire by Achour, Mohd Nor, and Mohd Yusoff (2016) was adopted and validated to measure the study participants' spiritual wellbeing. This questionnaire is a 21-item questionnaire divided into three domains: belief, extrinsic religiosity, and intrinsic religiosity. This questionnaire uses 5-point Likert scale response formats, ranging from (1) strongly disagree to (5) strongly agree. Concerning the adopted spiritual wellbeing questionnaire's validity and reliability, each item factor loadings exceeded 0.55, thus meeting the significant essential level of convergent validity. Furthermore, the Cronbach's coefficient as an estimate is 0.812 , and the Cronbach's value for all dimensions ranged between 0.70 and 0.88 , indicating that the spiritual wellbeing questionnaire is reliable. Finally, the participant's total calorie intake was measured by capturing the food and beverages listed in the 24-hour dietary recall. The Nutritionist Pro $^{\mathrm{TM}}$ software is used to calculate the total calories from the participants' dietary intake.

\section{Data analysis}

SPSS Statistics version 23 is used to analyse the data. Pearson correlation is utilised to examine the relationship between spiritual wellbeing and dietary intake. A normality check will be undertaken before the test using the histogram, the Kolmogorov-Smirnov test, skewness, and kurtosis. Additionally, this study was ethically approved by the Institutional Research Ethics Committee (IREC2022-KON43).

\section{RESULTS}

This study recruited and analysed 100 female overweight and obese undergraduates. The majority of the participants are Malaysian $(99 \%)$, Malays $(97 \%)$ and single $(99 \%)$. The participants' mean (standard deviation) age was 23 years (1.936). Regarding academic achievement, all participants possessed diplomas from the Malaysian Higher School Certificate. In terms of self-reported BMI, the findings reveal that more than half of individuals are overweight, with a mean (standard deviation) BMI of $27.60 \mathrm{~kg} / \mathrm{m}^{2}$ (4.102). Additionally, the majority of participants had no prior medical history ( 88 $\%)$. In comparison, $12 \%$ of students reported having a history of medical disorders such as hypertension $(2 \%)$, asthma $(4 \%)$, allergic rhinitis (5\%), and moderate psoriasis (1\%) (see Table I).

Table I: The Socio-demographic background of the study participants, $n=100$

\begin{tabular}{lccc}
\hline Variable & $\begin{array}{c}\text { Frequ } \\
\text { ency } \\
\text { (n) }\end{array}$ & $\begin{array}{c}\text { Perce } \\
\text { ntage } \\
(\mathbf{\%})\end{array}$ & $\begin{array}{c}\text { Mean } \\
\text { (SD) }\end{array}$ \\
\hline Age (years) & & & $\begin{array}{c}23.95 \\
(1.099)\end{array}$ \\
\hline $\begin{array}{l}\text { Country of } \\
\text { Origin }\end{array}$ & & & \\
Malaysian & 99 & 99.0 & \\
Non- & 1 & 1.0 & \\
Malaysian & & & \\
\hline
\end{tabular}

Ethnic

\begin{tabular}{lcc} 
Malay & 97 & 97.0 \\
Others & 3 & 3.0 \\
\hline
\end{tabular}

\section{Education}

Malaysian

Higher School $\quad 100 \quad 100.0$

Certificate

Marital Status

$\begin{array}{lcc}\text { Single } & 99 & 99.0 \\ \text { Married } & 1 & 1.0\end{array}$

\section{Medical}

History

\begin{tabular}{lccc} 
None & 88 & 88.0 & \\
Hypertension & 2 & 2.0 & \\
Asthma & 4 & 4.0 & \\
$\begin{array}{l}\text { Allergic } \\
\text { rhinitis }\end{array}$ & 5 & 5.0 & \\
Mild psoriasis & 1 & 1.0 & \\
\hline $\begin{array}{l}\text { Weight } \\
\text { (kilogram) }\end{array}$ & & 68.84 \\
\hline Height (meter) & & & $(12.097)$ \\
\hline Body Mass & & & 1.58 \\
Index (kg/m $\mathbf{m}^{2}$ ) & & & $(0.058)$ \\
\hline
\end{tabular}

\section{Spiritual Well-being}

The research participants' spiritual wellbeing is classified into three domains: belief, intrinsic, and extrinsic religiosity. The mean (standard deviation) and percentage score for each domain are shown in Table II. The mean 
(standard deviation) of belief is 39.41 (1.35), whereas the mean (standard deviation) of extrinsic and intrinsic religiosity is 32.84 (3.83) and 18.94 (4.04), respectively. According to the percentages referred to each domain, the study participants scored belief as the highest (98.5 $\%)$, followed by extrinsic (82.1\%) and intrinsic religiosity $(82.1 \%)(75.8 \%)$.

Table II: The spiritual well-being of the study participants, $\mathrm{n}=100$

\begin{tabular}{|c|c|c|c|c|}
\hline Domains & Min & Max & $\begin{array}{l}\text { Mean } \\
\text { (SD) }\end{array}$ & $\begin{array}{c}\text { Perc } \\
\text { enta } \\
\text { ge } \\
\mathbf{( \% )}\end{array}$ \\
\hline Belief & 32 & 40 & $\begin{array}{l}39.41 \\
(1.35)\end{array}$ & 98.5 \\
\hline $\begin{array}{l}\text { Extrinsic } \\
\text { Religiosity }\end{array}$ & 20 & 40 & $\begin{array}{l}32.84 \\
(3.83) \\
\end{array}$ & 82.1 \\
\hline $\begin{array}{l}\text { Intrinsic } \\
\text { Religiosity }\end{array}$ & 10 & 25 & $\begin{array}{l}18.94 \\
(4.04) \\
\end{array}$ & 75.8 \\
\hline Total Score & 72 & 105 & $\begin{array}{l}91.19 \\
(7.07)\end{array}$ & 86.5 \\
\hline
\end{tabular}

Note: The percentage (\%) is calculated by dividing the mean score to the maximum score and multiplying with 100

Belief is the first domain in the spiritual wellbeing questionnaire. Table III presents the responses of each item in this domain. Based on the findings, the study participants' mean scores were between 4.65 and 4.98 . The lowest mean score (4.65) was related to the purpose of prayer in securing a happy a peaceful life. On the other hand, the participants scored highest (4.98) in three questions related to the pillar of Islam, including the declaration of "Syahadah" or the one God and prophet Muhammad (peace be upon him) as His Messenger, the act of fasting in the month of Ramadhan and the holy Quran is the words of Allah.

Extrinsic religiosity in the second subdomain of spiritual wellbeing questionnaire. Table IV presented the study participants' responses in items under the extrinsic religiosity subdomain. From the findings, it is notable that the average score of responses is between 3.19 and 4.90. The highest mean score (4.90) was in response to the question of "I believe that more Islamic programs, channels should be offered." On the other hand, the lowest mean score (3.19) was the response for the question on the practice of praying Nawafil (sunat) and qiamullail prayer.
Table III: Responses of the study participants in belief subdomain of spiritual wellbeing, $\mathrm{n}=\mathbf{1 0 0}$

\begin{tabular}{|c|c|c|}
\hline Items & Mean & sd \\
\hline $\begin{array}{l}\text { I believe that prayer as } \\
\text { ordered by God and his } \\
\text { prophet is crucial to the life of } \\
\text { a Muslim. }\end{array}$ & 4.94 & .239 \\
\hline $\begin{array}{l}\text { I believe and declare that no } \\
\text { other God but Allah and } \\
\text { Muhammad is God's final } \\
\text { prophet. }\end{array}$ & 4.98 & .141 \\
\hline $\begin{array}{l}\text { I believe that fasting during } \\
\text { the holy period of Ramadan is } \\
\text { one of the responsibilities of } \\
\text { Muslims that is important to } \\
\text { do. }\end{array}$ & 4.98 & 141 \\
\hline $\begin{array}{l}\text { I believe that there will be the } \\
\text { end of time when people will } \\
\text { be judged according to how } \\
\text { they live their life in this } \\
\text { world. }\end{array}$ & 4.93 & 293 \\
\hline $\begin{array}{l}\text { I believe that Quran is the } \\
\text { word of Allah, thus its } \\
\text { authority is justified. }\end{array}$ & 4.98 & 141 \\
\hline $\begin{array}{l}\text { I believe that almsgiving } \\
\text { (Zakat) is very important in } \\
\text { the life of a good Muslim to be } \\
\text { paid every year. }\end{array}$ & 4.97 & .171 \\
\hline $\begin{array}{l}\text { Religion is especially } \\
\text { important to me because it } \\
\text { answers many questions } \\
\text { about the meaning of life. }\end{array}$ & 4.98 & 141 \\
\hline $\begin{array}{l}\text { The purpose of prayer is to } \\
\text { secure a happy and peaceful } \\
\text { life. }\end{array}$ & 4.65 & .702 \\
\hline
\end{tabular}

Table $\mathrm{V}$ present the mean (sd) of the responses to each item that represents the intrinsic religiosity of the study participants. There are five questions pertaining to intrinsic religiosity. The finding showed that the highest mean score (4.65) was the perception that religion can comfort when sorrows and misfortune strike. On the other hand, the lowest mean score was in response to the question, "It does not matter so much what I believe as long as I lead a moral life." 
Table IV: Responses of the study participants in extrinsic religiosity subdomain of spiritual wellbeing, $\mathrm{n}=\mathbf{1 0 0}$

\begin{tabular}{|c|c|c|}
\hline Items & Mean & sd \\
\hline $\begin{array}{l}\text { I believe that more Islamic } \\
\text { programs, channels should } \\
\text { be offered. }\end{array}$ & 4.90 & .362 \\
\hline $\begin{array}{l}\text { I will send my kids to } \\
\text { Islamic schools and not to } \\
\text { secular schools. }\end{array}$ & 3.84 & .972 \\
\hline $\begin{array}{l}\text { If not prevented by } \\
\text { unavoidable circumstances, } \\
\text { I pray at the Mosque. }\end{array}$ & 3.82 & .892 \\
\hline $\begin{array}{l}\text { I believe that praying at the } \\
\text { Mosque is an added benefit } \\
\text { rather praying at home or at } \\
\text { work. }\end{array}$ & 4.55 & .642 \\
\hline $\begin{array}{l}\text { I believe that Nawafil } \\
\text { (sunat) and qiamullail } \\
\text { prayers are extremely } \\
\text { beneficial for Muslims. }\end{array}$ & 4.86 & .403 \\
\hline $\begin{array}{l}\text { I always pray Nawafil } \\
\text { (sunat) and qiamullail } \\
\text { prayer. }\end{array}$ & 3.19 & .849 \\
\hline $\begin{array}{l}\text { One reason for my being a } \\
\text { member of a Mosque (or } \\
\text { attending religious sessions) } \\
\text { is that such membership } \\
\text { helps to establish a person } \\
\text { in the community. }\end{array}$ & 3.86 & .954 \\
\hline $\begin{array}{l}\text { A primary reason for my } \\
\text { interest in religion is that } \\
\text { my Mosque or my affiliation } \\
\text { with a religious group has } \\
\text { pleasant social activities. }\end{array}$ & 3.82 & 1.029 \\
\hline
\end{tabular}

Table V: Responses of the study participants in intrinsic religiosity subdomain of spiritual wellbeing, $n=100$

\begin{tabular}{llc}
\hline \multicolumn{1}{c}{ Items } & Mean & sd \\
\hline $\begin{array}{l}\text { I find it necessary to } \\
\text { compromise my religious } \\
\text { beliefs in order to protect my } \\
\text { social and economic interest. }\end{array}$ & 3.93 & 1.257 \\
\hline $\begin{array}{l}\text { It does not matter so much } \\
\text { what I believe as long as I }\end{array}$ & 2.97 & 1.453 \\
lead a moral life. & & \\
\hline $\begin{array}{l}\text { I pray mainly because I have } \\
\text { been taught to pray. }\end{array}$ & 3.13 & 1.475 \\
\hline $\begin{array}{l}\text { The primary purpose of } \\
\text { prayer is to gain relief and } \\
\text { protection. }\end{array}$ & 4.26 & .991 \\
\hline $\begin{array}{l}\text { What religion offers me most } \\
\text { is comfort when sorrows } \\
\text { and misfortune strike. }\end{array}$ & 4.65 & .657 \\
\hline
\end{tabular}

\section{Dietary Intake}

The 24-hour dietary recall was used to analyse the dietary intake in this study. The raw data from the dietary recall was retrieved and processed to determine the study participants estimated total calorie intake. According to the findings, the mean (standard deviation) for total calories consumed by study participants was 1737.32 (636.54) kcal/day. Lunch (583.75 $\mathrm{kcal} /$ day) supplied the most calories, followed by dinner (482 kcal/day) and breakfast (399 $\mathrm{kcal} /$ day). The study participants consumed an average of $153 \mathrm{kcal}$ per day for their afternoon tea and $119 \mathrm{kcal}$ per day for their late-night snack, respectively (see Table VI).

Table VI: Total calories intake of the study participants based on the mealtimes, $n=100$

\begin{tabular}{|c|c|c|}
\hline \multirow[t]{2}{*}{ Mealtimes } & \multicolumn{2}{|c|}{$\begin{array}{l}\text { Calories } \\
\text { (kcal/day) }\end{array}$} \\
\hline & mean & sd \\
\hline Breakfast & 399.25 & 284.27 \\
\hline Lunch & 583.75 & 281.57 \\
\hline Afternoon tea & 153.11 & 248.21 \\
\hline Dinner & 482.02 & 275.42 \\
\hline Late-night Snack & 119.18 & 202.67 \\
\hline $\begin{array}{l}\text { Total calories intake } \\
\text { (kcal/day) }\end{array}$ & 1737.32 & 636.54 \\
\hline
\end{tabular}

Association between Spiritual Well-being and Dietary Intake

The association between spiritual wellbeing and dietary intake was analysed in order to discover whether belief, intrinsic and extrinsic religiosity factors influence participants' eating. The Pearson correlation test revealed no significant relationship between the three spiritual wellbeing subdomains and the study participants' total calorie intake (Table VII).

Table VII: Correlation between total score of religiosity and total calories of participants, $\mathbf{n}=\mathbf{1 0 0}$

\begin{tabular}{|c|c|c|}
\hline \multirow[t]{2}{*}{ Variables } & \multicolumn{2}{|c|}{$\begin{array}{l}\text { Dietary intake } \\
\text { (total calories) }\end{array}$} \\
\hline & $\mathbf{r}$ & $p$-value \\
\hline $\begin{array}{l}\text { Spiritual wellbeing } \\
\text { subdomains }\end{array}$ & 0.078 & 0.439 \\
\hline Belief & -0.043 & 0.668 \\
\hline Extrinsic religiosity & -0.027 & 0.788 \\
\hline Intrinsic religiosity & 0.078 & 0.439 \\
\hline
\end{tabular}




\section{DISCUSSION}

This study found that female university students with overweight and obesity have the highest score for the belief, followed by the extrinsic and intrinsic religiosity. These three subdomains of spiritual wellbeing have varying effects on an individual's wellbeing. According to Yuen and Li, those with intrinsic religiosity seek spiritual development in religion and actively carry out their beliefs, whereas those with extrinsic religiosity seek religion for other reasons, including personal and social purposes (11). In the context of this study, a higher extrinsic religiosity score than an intrinsic religiosity score shows that female university students value religion as a means of achieving personal comfort and social relationships. This is demonstrated by the high score on extrinsic religiosity items such as "I believe that more Islamic shows, channels, and programmes should be offered" and "I believe that praying at the Mosque is an added benefit to praying at home or at work." These two items demonstrate a female university student's belief in religion as a networking tool. Additionally, religion is a platform for personal comfort, as participants believe that additional prayers such as sunat payer and qiamullail are particularly helpful for Muslims. Nonetheless, You and Lim reported that women believe that an extrinsically motivated religious activity, such as praying for consolation and protection or socialising for friendship, does not facilitate their pursuit for life purpose, and may have a negative influence on the quality of life (12).

With regards to the dietary intake of female university students with an elevated BMI, the findings show that the study participants' total daily calorie intake (1732 kcal/day) is within the Ministry of Health's recommended range. The recommended daily caloric intake for a female of average age 24 is between 1610 and $2310 \mathrm{kcal}$, depending on their level of physical activity (13). While the caloric distribution by mealtime is adequate, the fact that students consume an average of $120 \mathrm{kcal} /$ day in latenight snacks is concerning. Ahmad et al. discovered that late-night snacking is linked with an increase in BMI and a decline in grade point average among university students (14).

Additionally, this study investigated the relationship between spiritual wellbeing and dietary intake among female university students in peninsular Malaysia who are overweight or obese. The results suggest that there is no significant association between spiritual wellbeing in each of the subdomains studied, including belief, intrinsic and extrinsic religiosity, and total calorie intake. Though prior research has demonstrated the favourable impacts of spirituality on dietary habits $(9,15)$, this study discovered that a strong spirituality level might have no significant effect on the dietary intake of overweight and obese female university students. The finding may be related to mental health wellbeing, given Horton, Timmerman, and Brown observed that religious commitment could create internal conflict, pushing individuals to have high expectations of themselves, thus linked to eating disorders (16). Apart from that, the university lifestyle may have a more substantial influence on students' dietary intake. Therefore, spirituality elements can be considered to have a minimal effect on the dietary intake of female university students with an elevated BMI.

However, the results of this study should be interpreted cautiously for several inevitable limitations. Firstly, a small sample size due to the constraint in recruiting the participants during the Covid-19 pandemic might have limited the generalizability of the findings. Additionally, self-reported BMI and dietary intake data may contribute to measurement bias.

\section{CONCLUSION}

In conclusion, this study reported that overweight and obese female students at a university in Peninsular Malaysia hold a high level of spiritual wellbeing and consume overall daily recommended calorie intake. Consequently, this study implies that spiritual wellbeing has a minimal effect on the study participants' dietary intake. Additional dietary intake measures, such as the assessment of micronutrients and macronutrients, should be included in future studies to obtain a more meaningful result. Finally, a large-scale investigation is necessary to validate the findings regarding the association between spiritual wellbeing and dietary intake among overweight and obese female university students in Malaysia. 


\section{CONFLICT OF INTEREST}

The authors declare that they have no known competing financial interests or personal relationships that could have appeared to influence the work reported in this study.

\section{ACKNOWLEDGEMENT}

Kulliyyah of Nursing, International Islamic University Malaysia for supporting this research.

\section{REFERENCES}

1. Pi-Sunyer $X$. The medical risks of obesity. Postgrad Med. 2009;121(6):21-33.

2. World Health Organization (WHO). Obesity and Overweight. 2020.

3. Lee YY, Muda WAMW. Dietary intakes and obesity of malaysian adults. Nutr Res Pract. 2019;13(2):159-68.

4. Abdul N, Kutty M, Ru TY, Hwang V, Chiang Q, Zhi WY. Association of Dietary Habits and Body Mass Index among University Students in Malaysia. IOSR J Nurs Heal Sci Ver I [Internet]. 2015;4(5):2320-1940. Available from: www.iosrjournals.org

5. Raheema CCZ, Omar MMM. Five pillars of Islam in relation to physical health, spiritual health and nursing implications. Int Med J Malaysia. 2016;17(Specialissue1):105-8.

6. Achour $M$, Roslan $M$, Nor $M$. Islamic Personal Religiosity as a Moderator of Job Strain and Employee' s Wellbeing: The Case of Malaysian Academic and Administrative Staff. 2015;

7. Ar A, Aidalina M. A Review of the Islamic Approach in Public Health Practices. Int J Public Heal Clin Sci. 2014;1(2):1-13.

8. Hassan SH. Effects of Religious Behavior on Health-Related Lifestyles of Muslims in Malaysia. J Relig Health. 2015;54(4):123848.

9. Michopoulou E, Jauniškis P. Exploring the relationship between food and spirituality: A literature review. Int J Hosp Manag. 2020;87.

10. Ministry of Health. Clinical Practice Guideline: Management of Obesity. 2004.

11. Yuen $\mathrm{A}, \mathrm{Li}$ C. Effects of intrinsic and extrinsic religiosity on wellbeing through meaning in life and its gender difference among adolescents in Hong Kong: A mediation study. Curr Psychol. 2021;

12. You S, Lim SA. Religious Orientation and Subjective Well-being: The Mediating Role of Meaning in Life. J Psychol Theol. 2019;47(1):34-47.

13. National Coordinating Committee on Food and Nutrition (NCCFN). Recommended Nutrient Intakes for Malaysia. Ministry of Health; 2017.

14. Ahmad M, Kashoo FZ, Alqahtani M, Waqas SAMI, Rizvi M, Bushra A. Relation Between Night Eating Syndrome and Academic Grades Among University Students. Turkish J Endocrinol Metab. 2019;23(2):85-91.

15. Tan MM, Chan CKY, Reidpath DD. Faith, food and fettle: Is individual and neighborhood religiosity/spirituality associated with a better diet? Religions. 2014;5(3):801-13.

16. Horton SEB, Timmerman GM, Brown A. Factors influencing dietary fat intake among black emerging adults. J Am Coll Heal. 2018;66(3):155-64. 